\title{
Ideological and Political Education in the Perspective of Innovation and Development Philosophy of College Students
}

\author{
Zhang Xuexing \\ Shandong University Of Arts, Shandong China250030
}

Keywords: Political education; College development; Innovative ideas; Importance

\begin{abstract}
In the ideological and political education of colleges, the concept of innovation plays an important role, because the current social development needs talented people with innovative spirit and ability. Therefore, in the process of carrying out ideological and political education in colleges, we must conscientiously implement the party's ideology, attach importance to the integration of innovative ideas, actively explore ways to adapt to ideological and political education in the new period, make college students' ideological and political education work in an orderly and positive manner and give play to their correct ideas.

The five major development concepts proposed by the party (innovation, coordination, green, openness and sharing) are not only the insistence and recognition of Marxism, but also indicate the direction of development for China's efforts to build socialism with Chinese characteristics in light of China's actual national conditions. As a top priority in development concepts, the importance of innovative ideas is undeniable, because both social and corporate advancement require innovation that can adapt to the trend of the times. Therefore, in carrying out the ideological and political education for students in colleges, we should adhere to the party's ideology and development line, earnestly implement innovative ideas in education and actively cultivate a large number of innovative talents for social development.
\end{abstract}

\section{The significance of integrating creative ideas in college students' ideological and political education}

It is an important measure to improve the pertinence and effectiveness of college students' ideological and political education

For the ideological and political education of college students, educators must keep up with the development of the times so that they are targeted and effective. At present, innovative ideas are not evident in the work of ideological and political education for college students, and the content of education is lacking in pertinence and effectiveness, and the effect is not obvious. Under the guidance of the Party's innovative ideas, it is inevitable that the ideological and political education of college students must be updated in time to reflect the subjective status of students and to cultivate students' awareness of innovation so that they can be fully developed. However, judging from the current actual situation, most colleges only think that students are the object of education and the object. This kind of one-sided thinking will only affect the effective development of the ideological and political education of college students. At the same time, the concept of innovative development requires modern college students to have avant-garde ideas, to adapt to the new era of thinking and to solve the current ideological confusion of college students. However, the reality of education is the lack of innovation in education carriers, and the lack of educational channels is an obvious problem, and it is a serious violation of the needs of the development of college students' ideological and political education.

In addition, under the guidance of the concept of innovative development, the ideological and political education of college students should be integrated with social life, and they should actively pay attention to and respond to the society and avoid the existence of problems such as isolation caused by education in sorting out society. In other words, under the innovative concept, the ideological and political education of college students should not only conform to social development and cater to social trends, but also play an important role in transforming society and 
influencing society. Therefore, under the background of the concept of innovation and development, the pertinence and effectiveness of the ideological and political education of college students will inevitably be fully reflected, and this will lead to long-term development of education.

It is an important measure to improve undergraduate ideological and political education infection

For the cultivation of the ideological and political quality of college students, we can't rush to achieve success. Instead, we need to spend a lot of time and continuously promote the ideological and political quality of college students. In the new era, educators must actively develop innovation and promote the ideological and political education of college students to a new direction and a high degree of development. Under the guidance of innovative ideas, undergraduates' ideological and political education needs to renew ideological concepts, enrich educational content and explore new ways of education so as to increase the influence and influence of ideological and political education and effectively avoid problems such as developmental dilemmas. In addition, the ideological and political education of college students should adhere to the student's subjective role in linking with students' actual and life. The best way of education is to allow students to change in a subtle manner. By integrating innovative ideas into the work of ideological and political education for college students, the education work is more rational and realistic, and it is in line with the development of college students. Students are easy to understand and accept.

(3)It is an important measure to cope with the continuous progress of science and technology

The continuous development of scientific progress not only brings new opportunities for social development, but also brings about earthshaking influence on the life and learning of college students. Therefore, the ideological and political education for college students should conform to this trend and make innovations in teaching content. On the one hand, in the context of the common development of technology and the Internet, there has been a gradual emergence from the media. This is also great opportunity and challenge for the ideological and political education of college students. Because in the media environment, more and more software has been developed and promoted, such as Weibo and Wechat, which are commonly used in our lives and have become important ways for college students to obtain outside information. But at the same time, the problems that come with it are even more pronounced. Because in the face of a variety of information shocks, how can college students make correct judgments must be guided by correct ideas and concepts. In addition, in the context of self-media, the main body of information dissemination and communication methods have also changed, which means to use this advantage to effectively carry out ideological and political education for college students and provide students with more quality education services. This requires that colleges must have a sense of innovation, ans accept the influence and opportunities brought about by the media environment, strive to innovate teaching content and methods and comply with the needs of student development.

On the other hand, technology is a double-edged sword that has been recognized by the general public because the advancement of science and technology for social development is obvious. However, its negative effects also require people to pay attention to it. More and more college students are facing the quagmire that is shaped by technological progress. For example, mobile phones and digital electronic products are common in our lives. Although it has brought convenience to people's lives and work, more and more "bearer families" have become a phenomenon commonly found in society. This impact on college students can not be ignored, and even some college students are too addicted to it, and the consequences can be disastrous. Under this background, how to accelerate the innovation of university students' ideological and political education, correctly guide the university students to establish the correct ideology and values and cultivate good moral qualities have become urgent problems.

\section{The way of ideological and political education for college students from the perspective of innovation and development}

Changing the idea of ideological and political education for college students

In the new era, the ideological and political education of college students must be developed 
together with the times, and it is consistent with the development goals of education. Therefore, we must actively establish innovative ideas. First of all, educators must understand the importance of students' all-round development and regard it as the fundamental idea of ideological and political education. The main body of ideological and political education of college students is the active people. Therefore, the initiative and creativity of stimulating people should be regarded as the starting point of educational work, and the comprehensive quality of people should be regarded as the fundamental purpose of education. Therefore, educators need to have the ability to accurately grasp the characteristics of the era of social development, and seriously analyze the realistic demands of the development of college students. At the same time, education should be based on the principle of respecting students, understanding students, helping students and giving full play to the role of students in education. Secondly, as a ideological and political education worker in a modern society, we must have a socialized working philosophy. Ideological and political education can reflect the distinctive features of society, so the organization and implementation of education may be affected by some social environment.At the same time, the basic contradictions in the process of ideological and political education are mainly manifested in the contradiction and conflict between the ideological morality and psychological quality required in social development and the actual ability and level of the educational target. Therefore, in the work of ideological and political education, education should pay more attention to society, understand society and adapt to society. It should have a positive attitude toward hot issues in society, and ensure that education work is closely linked with social reality issues. Finally, ideological education for college students should reflect the concept of birth activation, which is to integrate education work into life, reflect life and connect students with reality. Educational work must avoid formalization, and education can only be effective in solving practical problems, so that students can be more easily accepted.

\section{Enriching the content of college students' ideological and political education}

Enriching and expanding the content of ideological and political education for university students has become a common demand for education and the development of the times. Although the current educational content already contains many aspects, such as world outlook, ethics and outlook on life, and the content is relatively diversified, it is not closely related to political development, economic level and cultural changes in the current period. Content needs further development, and this issue has also become an important factor that restricts the university students' thinking and behavior activities. It also brings new challenges to the ideological and political education of college students, especially in terms of educational content, it should be able to reflect the new era markings and provide guidance for college students to get better development in the new era. Moreover, under the influence of innovative ideas, the ideological and political education of college students should strengthen transformation in terms of ideas, systems, contents, functions, mechanisms, methods and incorporate innovative ideas, and better adapt to the development of the times.

As a key element of the ideological and political education of college students, the content of education must advance the characteristics of the times, actively explore new areas and reflect the pertinence and timeliness of the ideological and political education of college students. Under the current situation, it has brought new opportunities and challenges to traditional ideological and political education for university students. Whether they can win or not will require educators to make more efforts. The formalization of traditional ideological and political education methods has become more prominent. Direct instillation of theoretical knowledge or moral teaching with examples is a method commonly used by educators. This method of classroom interaction is less and does not solve students' actual problems. Under the new concept of development, it is required that the ideological and political education of college students be gradually extended from theoretical teaching to thematic educational activities, and the content of education has been adjusted to a certain extent, which clearly reflects the characteristics of the development of the times. Moreover, in the education work, it has achieved close integration with some difficult problems in the ideological and political education of college students, social real-time development and student characteristics ensuring the effectiveness of ideological and political education. 


\section{Conclusion}

Under the guidance of the Party's innovative ideas, it is inevitable that the ideological and political educators of colleges must update their concepts in a timely manner, reflect the subjective status of students, adhere to the principle of respecting students and make correct ideological guidance for students so that they can be fully developed. In addition, the times are constantly developing, and the contents of ideological and political education for college students must be able to achieve common development with the times, consistent with the development goals of education and constantly expand and enrich educational content.

\section{Reference}

[1]Weiping Qi. Five development concepts integrate into ideological and political education in universities: new tasks and new requirements[J].Ideological and Theoretical Education, 2016(5).

[2]Jinping Xi.Jinping Xi emphasized at the national ideological and political work conference for colleges that the ideological and political work must be carried out throughout the entire process of education to create a new situation for the development of higher education in China[N].People's Daily, 2016-12-09(1)

[3]Songqiang Wu.Research on college Students' ideological and political education under the background of social management innovation[J].Ideological Education Research,2014(2):101 105. 